\title{
Manganese oxide phases and morphologies: A study on calcination temperature and atmospheric dependence
}

\author{
Matthias Augustin ${ }^{* 1,2}$, Daniela Fenske ${ }^{1}$, Ingo Bardenhagen ${ }^{1}$, Anne Westphal ${ }^{1}$, \\ Martin Knipper ${ }^{2}$, Thorsten Plaggenborg ${ }^{2}$, Joanna Kolny-Olesiak ${ }^{2}$ and Jürgen Parisi ${ }^{2}$
}

\author{
Full Research Paper \\ Address: \\ ${ }^{1}$ Fraunhofer Institute for Manufacturing Technology and Advanced \\ Materials, Wiener Str. 12, 28359 Bremen, Germany and 2Department \\ of Physics, Energy and Semiconductor Research Laboratory, Carl \\ von Ossietzky University of Oldenburg, 26129 Oldenburg, Germany \\ Email: \\ Matthias Augustin* - matthias.augustin@ifam.fraunhofer.de \\ * Corresponding author

\section{Keywords:} \\ electrocatalytic activity; in situ X-ray diffraction; manganese glycolate; \\ manganese oxide nanoparticles; mesoporous $\alpha-\mathrm{Mn}_{2} \mathrm{O}_{3}$
}

Open Access

Beilstein J. Nanotechnol. 2015, 6, 47-59.

doi:10.3762/bjnano.6.6

Received: 16 June 2014

Accepted: 03 December 2014

Published: 06 January 2015

This article is part of the Thematic Series "Nanostructures for sensors, electronics, energy and environment II".

Guest Editor: N. Motta

(C) 2015 Augustin et al; licensee Beilstein-Institut.

License and terms: see end of document.

\begin{abstract}
Manganese oxides are one of the most important groups of materials in energy storage science. In order to fully leverage their application potential, precise control of their properties such as particle size, surface area and $\mathrm{Mn}^{x+}$ oxidation state is required. Here, $\mathrm{Mn}_{3} \mathrm{O}_{4}$ and $\mathrm{Mn}_{5} \mathrm{O}_{8}$ nanoparticles as well as mesoporous $\alpha-\mathrm{Mn}_{2} \mathrm{O}_{3}$ particles were synthesized by calcination of Mn(II) glycolate nanoparticles obtained through an economical route based on a polyol synthesis. The preparation of the different manganese oxides via one route facilitates assigning actual structure-property relationships. The oxidation process related to the different $\mathrm{MnO}_{x}$ species was observed by in situ X-ray diffraction (XRD) measurements showing time- and temperature-dependent phase transformations occurring during oxidation of the $\mathrm{Mn}(\mathrm{II})$ glycolate precursor to $\alpha-\mathrm{Mn}_{2} \mathrm{O}_{3}$ via $\mathrm{Mn}_{3} \mathrm{O}_{4}$ and $\mathrm{Mn}_{5} \mathrm{O}_{8}$ in $\mathrm{O}_{2}$ atmosphere. Detailed structural and morphological investigations using transmission electron microscopy (TEM) and powder XRD revealed the dependence of the lattice constants and particle sizes of the $\mathrm{MnO}_{x}$ species on the calcination temperature and the presence of an oxidizing or neutral atmosphere. Furthermore, to demonstrate the application potential of the synthesized $\mathrm{MnO}_{x}$ species, we studied their catalytic activity for the oxygen reduction reaction in aprotic media. Linear sweep voltammetry revealed the best performance for the mesoporous $\alpha-\mathrm{Mn}_{2} \mathrm{O}_{3}$ species.
\end{abstract}

\section{Introduction}

Manganese oxides are a class of inexpensive compounds with a high potential for nanostructuring, which makes them attractive candidates for various applications, for example, as basis ma- terials in supercapacitors and electrodes for Li-ion accumulators [1-3]. They exhibit high catalytic activity for different oxidation and reduction reactions due to the diversity in their $\mathrm{Mn}^{x+}$ 
cation oxidation states as well as morphological characteristics [4,5]. Many manganese oxide phases consist of tunnel structures built from $\mathrm{MnO}_{6}$ octahedra; these tunnels facilitate the access of reactants to the active reaction sites as well as the absorption of small molecules within the structure. The latter property is especially useful for application as molecular sieves and absorbents for the removal of toxic species from waste gases such as carbon monoxide and nitrogen oxide [6-8]. Additionally, manganese oxide structures exhibiting oxygen vacancies provide additional active sites for reduction and oxidation reaction intermediates, especially those involving oxygen. These properties are especially important for catalytic applications such as water oxidation [9-11] and the oxygen reduction and evolution reactions in metal/air battery systems [12-16]. Additionally, the advantages of manganese oxides can be enhanced by nanostructuring of the different species, which was recently shown by Zhang et al. [17]. In their report, better cyclability of Li-ion cells was obtained with anodes consisting of mesoporous $\mathrm{Mn}_{2} \mathrm{O}_{3}$ particles compared to $\mathrm{Mn}_{2} \mathrm{O}_{3}$ bulk powder electrodes [17].

Several nanoscale manganese oxide compounds can be prepared via calcination processes from suitable precursors [7,18-20]. Whereas many synthetic protocols yield manganese oxide species at the nanometer scale [21], for example, precipitation or the solvothermal route, these methods require long reaction times in the range of hours (up to $24 \mathrm{~h}$ ) and subsequent drying processes of up to 2 days [22-27]. The synthesis via oxidation of manganese metal nanoparticles by gas condensation must be followed by annealing in $\mathrm{O}_{2}$-containing atmospheres to obtain different manganese oxide species [28]. An advantage of the calcination route, on the other hand, is the conservation of the morphology and size of the precursor during this process, which is of special interest when considering the use of nanoscale precursor particles. Further advantages include a relatively short synthesis time of about 1 to $5 \mathrm{~h}$ and the fact that a single precursor can be used to obtain several different products. Additionally, the calcination procedure is the only way to obtain pure phase $\mathrm{Mn}_{5} \mathrm{O}_{8}$ [28-33].

Here, we present the synthesis of nanocrystalline Mn(II) glycolate by a polyol process and demonstrate its suitability as a precursor in the synthesis of different manganese oxides. The polyol process is a well-known route for the synthesis of metal glycolates, usually yielding disc-shaped particles with diameters and thicknesses in the range of 1 to $3 \mu \mathrm{m}$ and 100 to $250 \mathrm{~nm}$, respectively $[19,29,34,35]$. By applying milder reaction conditions (i.e., decreasing the synthesis temperature and increasing the reaction time), we obtained homogeneous, rectangular $\mathrm{Mn}(\mathrm{II})$ glycolate nanocrystals with diameters less than $25 \mathrm{~nm}$. The preparation of nanoscale precursor particles with uniform morphology is advantageous for the further synthesis of manganese oxides, because the control of the morphology and size of the particles is a major issue for their catalytic applications. The subsequent calcination process yielded $\mathrm{Mn}_{3} \mathrm{O}_{4}$ and $\mathrm{Mn}_{5} \mathrm{O}_{8}$ nanoparticles as well as mesoporous $\alpha-\mathrm{Mn}_{2} \mathrm{O}_{3}$ particles with high surface areas of 300 , 30 and $20 \mathrm{~m}^{2} / \mathrm{g}$, respectively. The nanostructures of the obtained $\mathrm{MnO}_{x}$ particles make them attractive candidates as highly active compounds in the field of catalysis and other applications in the field of energy storage. Furthermore, the synthesis presented in this study provides easy access to three different nanostructured $\mathrm{MnO}_{x}$ species via one calcination process. This is advantageous for the investigation of the properties of the manganese oxides, as it rules out any synthesiscaused effects. The temperature- as well as the time-dependent phase transformation processes occurring during the oxidation of $\mathrm{Mn}$ (II) glycolate to $\mathrm{Mn}_{3} \mathrm{O}_{4}, \mathrm{Mn}_{5} \mathrm{O}_{8}$ and $\alpha-\mathrm{Mn}_{2} \mathrm{O}_{3}$ were studied by in situ XRD measurements. A detailed study of the structural parameters of the manganese oxide products obtained after calcination in a temperature range from 320 to $550{ }^{\circ} \mathrm{C}$ in $\mathrm{Ar}$ and $\mathrm{O}_{2}$ atmosphere was performed using powder XRD.

\section{Results and Discussion Precursor synthesis}

The polyol process reported by Liu et al. [19] was modified to yield the $\mathrm{Mn}(\mathrm{II})$ glycolate precursor for the thermal decomposition to the various manganese oxides. During the heating of the compound to $170{ }^{\circ} \mathrm{C}$, a white precipitate appeared after $1 \mathrm{~h}$, which was identified as manganese glycolate containing large impurities of the dehydrated educt $\mathrm{Mn}$ (II) acetate dihydrate and the product of a side reaction, manganese oxalate $\left(\mathrm{MnC}_{2} \mathrm{O}_{4}\right.$, see Supporting Information File 1 for the powder XRD pattern of the product mixture). In order to obtain the pure $\mathrm{Mn}$ (II) glycolate precursor having homogeneous particle morphology, the reaction was continued at $170{ }^{\circ} \mathrm{C}$ until a white precipitate of pure $\mathrm{Mn}(\mathrm{II})$ glycolate appeared. This was verified by the X-ray diffraction pattern of the product after $7 \mathrm{~h}$ of synthesis as depicted in Figure 1. This product can be assigned to the trigonal brucite-type structure $(P \overline{3} \mathrm{~m} 1)$ reported for $\mathrm{Mn}$ (II) glycolate by other groups $[19,29,35]$. A mean Scherrer crystallite size of $17 \pm 8 \mathrm{~nm}$ was calculated for the Mn(II) glycolate particles. The interlayer distance along the [001] direction was calculated to be $8.2 \AA$. This value corresponds to the lattice constant, $c$, and is consistent with reports by other groups who measured lattice constants of $c=8.3 \AA$ and $c=8.27 \AA$ for Mn and Co glycolate, respectively [34,35]. As Sun et al. [35] did not use tetraethylene glycolate (TEG) in their synthesis, it is proposed here that TEG anions are not part of the Mn(II) glycolate structure presented in this report, as $c$ would be increased even beyond $8.2 \AA$ in this case. Hence, it can be concluded that TEG acts only as a stabilizing ligand to the $\mathrm{Mn}(\mathrm{II})$ glycolate parti- 
cles. This and the milder synthesis conditions applied are considered to be the reasons for the relatively small crystallite sizes, differing by one order of magnitude from the data presented to date in the literature $[19,29,35]$. Inorganic compounds with a brucite structure such as $\mathrm{Mg}(\mathrm{OH})_{2}, \mathrm{Co}(\mathrm{OH})_{2}$, $\mathrm{Ca}(\mathrm{OH})_{2}$ and $\mathrm{Ni}(\mathrm{OH})_{2}$, exhibit lattice constant $c$ between 4.6 and $4.9 \AA$ and $a$ in the range from 3.1 to $3.6 \AA$. For $\mathrm{Mn}(\mathrm{II})$ glycolate, the $\mathrm{Mn}-\mathrm{Mn}$ distance (corresponding to lattice constant $a$ ) was calculated to be $3.2 \AA$ from the (110) reflection, which is also in accordance with the findings of Sun et al. [35] who proposed that the structure widening in the $c$ direction is due to the long-chain alcoholate anions interconnecting the metal-oxygen sheets in the $a b$ plane of the unit cell.

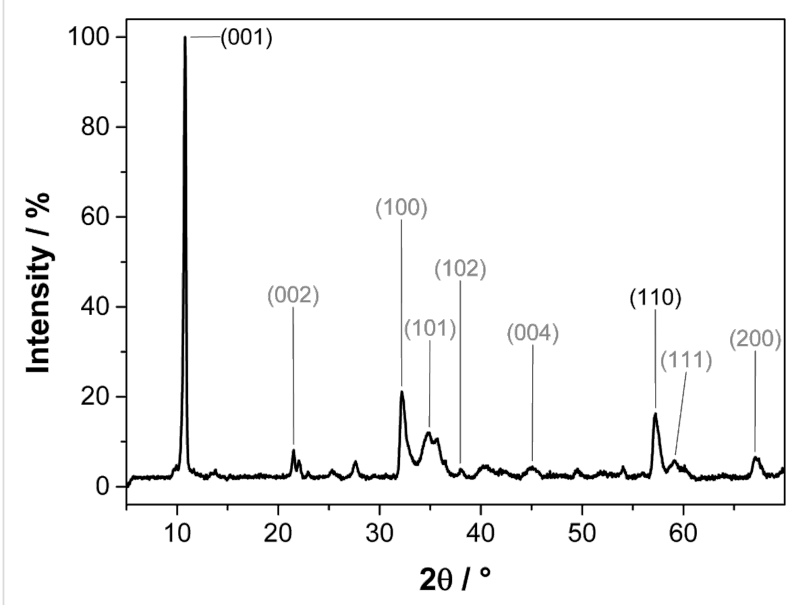

Figure 1: Powder XRD pattern of Mn(II) glycolate particles synthesized for $7 \mathrm{~h}$; literature assignments [35] (black) and calculated reflection assignments (grey) are given for the brucite structure exhibiting lattice constants of $a=b=3.2 \AA$ and $c=8.2 \AA$.
The morphology of the as-synthesized Mn(II) glycolate was investigated with SEM and TEM measurements. Figure 2a depicts SEM images of spherical Mn(II) glycolate particles with diameters up to $1 \mu \mathrm{m}$. These particles are hollow, which is deduced from the particles with broken outer shells (highlighted by white frames). Figure $2 b$ shows a TEM image of one of these spherical particles, broken under the electron beam. A closer look reveals that the spheres are in fact agglomerates of rectangular $\mathrm{Mn}$ (II) glycolate nanoparticles with dimensions less than $15 \mathrm{~nm}$ (Figure 2c). The observed sizes of the particle are in good agreement with the calculated Scherrer crystallite sizes from the XRD pattern shown in Figure 1. The small dimensions of the particles make the synthesized Mn(II) glycolate a perfect precursor for the generation of manganese oxides by thermal decomposition processes.

\section{The oxidation process to different $\mathrm{MnO}_{x}$ species}

In order to investigate the temperature dependence of the oxidation process of $\mathrm{Mn}(\mathrm{II})$ glycolate, in situ X-ray diffractograms were recorded in the presence of $\mathrm{O}_{2}$ while heating the precursor to $700{ }^{\circ} \mathrm{C}$ at a heating rate of $2 \mathrm{~K} / \mathrm{min}$ (see Figure 3 ). The $2 \theta$ region of $17.6-23.8^{\circ}$ was monitored during the measurement, as it contains the reflections of the species that are most likely to be generated during the oxidation process $\left(21.5^{\circ}\right.$ ( $\mathrm{Mn}(\mathrm{II})$ glycolate, $\square)$ [19], $18.0^{\circ}\left(\mathrm{Mn}_{3} \mathrm{O}_{4}, *\right)$ [36], 18.1 ${ }^{\circ}$ and $21.6^{\circ}\left(\mathrm{Mn}_{5} \mathrm{O}_{8},+\right)$ [31], and $23.2^{\circ}\left(\alpha-\mathrm{Mn}_{2} \mathrm{O}_{3}, \circ\right)$ [37]). The reflection of $\mathrm{Mn}$ (II) glycolate at $21.5^{\circ}$ is observed until a temperature of about $185{ }^{\circ} \mathrm{C}$ is reached, where a sudden decrease of the intensity (including the background intensity) is observed in the diffraction patterns due to the loss of organic species from the sample. This loss derives from the decomposition of the organic ligands and anions by oxidation; this is

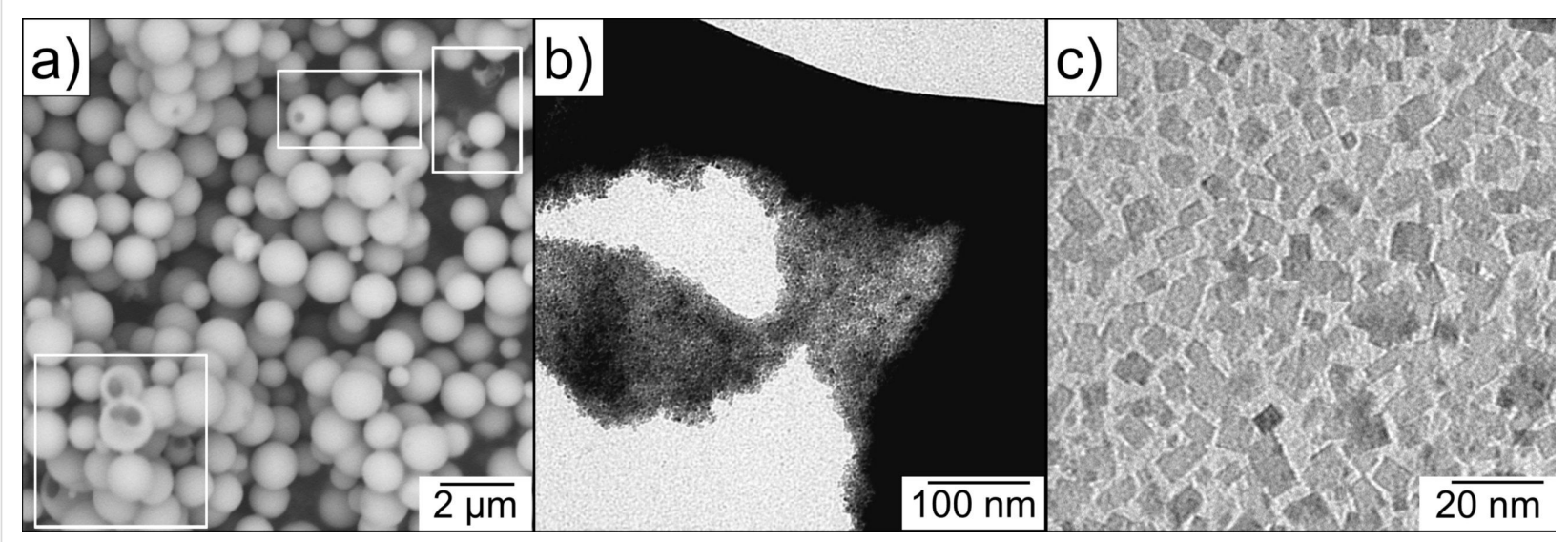

Figure 2: a) SEM and b) and c) TEM images of the Mn(II) glycolate particles. Particles with broken outer shells are highlighted by white frames in panel (a). 
dependent on the temperature as well as on the partial pressure of oxygen. The $\mathrm{Mn}_{3} \mathrm{O}_{4}$ reflection at $18.0^{\circ}$ immediately evolves at about $185{ }^{\circ} \mathrm{C}$ after the $\mathrm{Mn}$ (II) glycolate reflection has vanished. The appearance of the $\mathrm{Mn}_{5} \mathrm{O}_{8}$ reflection at $21.6^{\circ}$ at about $350{ }^{\circ} \mathrm{C}$ is accompanied by the decreasing intensity of the $\mathrm{Mn}_{3} \mathrm{O}_{4}$ reflection at $18.0^{\circ}$ as well as an increasing intensity of the $\mathrm{Mn}_{5} \mathrm{O}_{8}$ reflection at $18.1^{\circ}$, which is attributed to the slow oxidation of $\mathrm{Mn}_{3} \mathrm{O}_{4}$ to $\mathrm{Mn}_{5} \mathrm{O}_{8}$. The $\mathrm{Mn}_{3} \mathrm{O}_{4}$ reflection at $18.0^{\circ}$ disappears at about $440{ }^{\circ} \mathrm{C}$, indicating a completed oxidation process of $\mathrm{Mn}_{3} \mathrm{O}_{4}$ to $\mathrm{Mn}_{5} \mathrm{O}_{8}$. Both reflections assigned to $\mathrm{Mn}_{5} \mathrm{O}_{8}$ disappear at $550{ }^{\circ} \mathrm{C}$ after the appearance of the intense $\alpha-\mathrm{Mn}_{2} \mathrm{O}_{3}$ reflection at $23.2^{\circ}$ at a temperature of about $530{ }^{\circ} \mathrm{C}$.

Hence, in $\mathrm{O}_{2}$ atmosphere, $\mathrm{Mn}_{3} \mathrm{O}_{4}$ is obtained at temperatures between 185 and $400{ }^{\circ} \mathrm{C}, \mathrm{Mn}_{5} \mathrm{O}_{8}$ between 400 and $550{ }^{\circ} \mathrm{C}$ and $\alpha-\mathrm{Mn}_{2} \mathrm{O}_{3}$ above $530{ }^{\circ} \mathrm{C}$. This oxidation of $\mathrm{Mn}_{3} \mathrm{O}_{4}$ to $\mathrm{Mn}_{5} \mathrm{O}_{8}$ (rather than to $\mathrm{Mn}_{2} \mathrm{O}_{3}$ ) was found by Feitknecht [30] to take place during the heating of $\mathrm{Mn}_{3} \mathrm{O}_{4}$ particles at temperatures between 250 and $550{ }^{\circ} \mathrm{C}$ in an atmosphere containing more than $5 \% \mathrm{O}_{2}$. Feitknecht attributed this $\mathrm{Mn}_{3} \mathrm{O}_{4} / \mathrm{Mn}_{5} \mathrm{O}_{8}$ phase transformation to a one-phase mechanism for $\mathrm{Mn}_{3} \mathrm{O}_{4}$ particles exhibiting BET surface areas of more than $10 \mathrm{~m}^{2} / \mathrm{g}$. That is, the small particle diameters provide sufficient reaction sites for oxidation of the surface of the particles. Feitknecht also reported similar reflection intensities for $\mathrm{Mn}_{3} \mathrm{O}_{4}$ and $\mathrm{Mn}_{5} \mathrm{O}_{8}$ with a linear decrease and increase, respectively, during the oxidation process. The subsequent reduction process of $\mathrm{Mn}_{5} \mathrm{O}_{8}$ to $\alpha-\mathrm{Mn}_{2} \mathrm{O}_{3}$ was observed by several groups to take place even in oxygen-containing atmospheres at temperatures greater than $500{ }^{\circ} \mathrm{C}[26,32,37]$.

The Mn(II) glycolate particles were calcined for $2 \mathrm{~h}$ in $\mathrm{Ar}$ and $\mathrm{O}_{2}$ atmospheres at different temperatures between 320 and $550{ }^{\circ} \mathrm{C}$ to investigate the dependence of the particle size, their morphology and the $\mathrm{Mn}^{x+}$ oxidation state in the resulting manganese oxide on the calcination temperature and atmosphere. The X-ray diffractograms of the resulting species as well as the reference patterns are shown in Figure 4; the crystalline phases observed in the XRD patterns are listed in Table 1.

The tetragonal $\mathrm{Mn}_{3} \mathrm{O}_{4}$ phase (ICDD 01-075-1560, I4 1 /amd) is observed in the powder XRD patterns after calcination at temperatures between 320 and $450{ }^{\circ} \mathrm{C}$ in both atmospheres. It is, however, obtained as a pure phase only at temperatures up to $400{ }^{\circ} \mathrm{C}$ in $\mathrm{Ar}$ and up to $350{ }^{\circ} \mathrm{C}$ in $\mathrm{O}_{2}$ (see also Table 1). The presence of $\mathrm{Mn}_{3} \mathrm{O}_{4}$ in $\mathrm{O}_{2}$ atmosphere could also be observed in

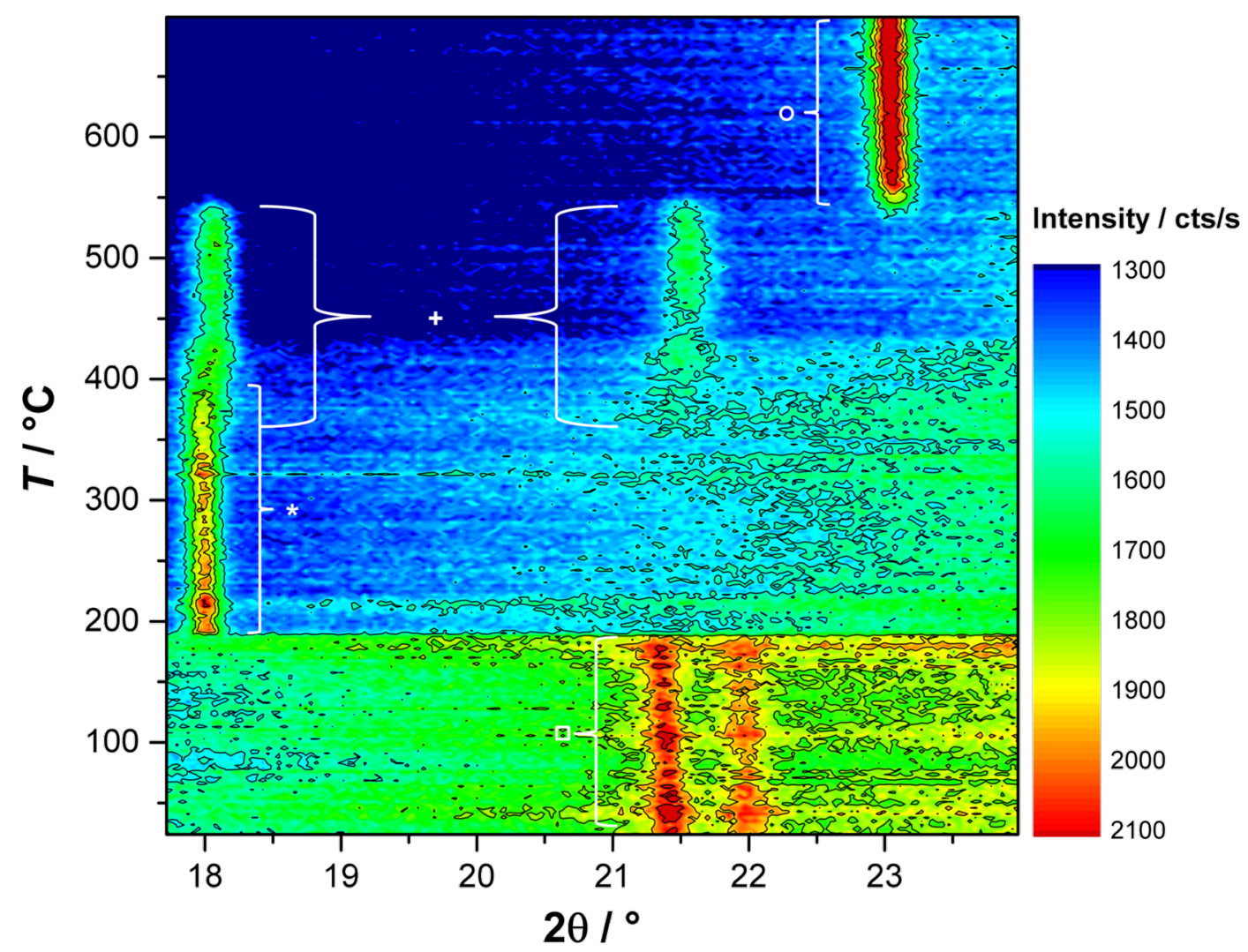

Figure 3: In situ XRD patterns recorded in a pure $\mathrm{O}_{2}$ flow while heating the $\mathrm{Mn}(\mathrm{II})$ glycolate precursor to $700{ }^{\circ} \mathrm{C}$ at $2 \mathrm{~K} / \mathrm{min}$; reflexes denoted are: $\mathrm{Mn}(\mathrm{II})$ glycolate (口), $\mathrm{Mn}_{3} \mathrm{O}_{4}(*), \mathrm{Mn}_{5} \mathrm{O}_{8}(+)$ and $\alpha-\mathrm{Mn}_{2} \mathrm{O}_{3}(\circ)$. 


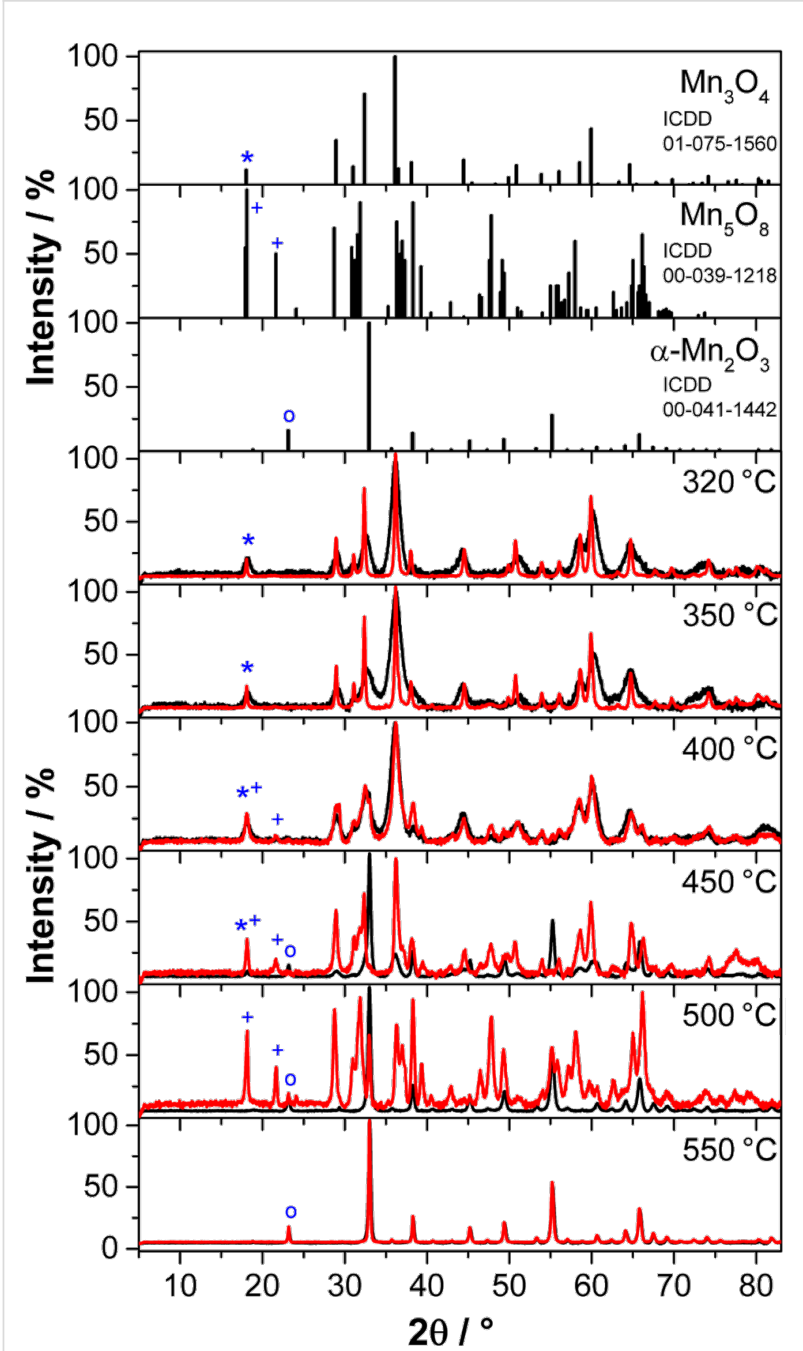

Figure 4: Powder XRD patterns of the manganese oxide particles obtained after calcination of the Mn(II) glycolate for $2 \mathrm{~h}$ at different temperatures in an $\mathrm{Ar}$ (black) and an $\mathrm{O}_{2}$ (red) flow of $50 \mathrm{NL} / \mathrm{h}$. Reference patterns are depicted at the top for $\mathrm{Mn}_{3} \mathrm{O}_{4}(*), \mathrm{Mn}_{5} \mathrm{O}_{8}(+)$ and $\mathrm{a}-\mathrm{Mn}_{2} \mathrm{O}_{3}(\mathrm{\circ})$, where the symbols indicate the respective low-angle reflections.

the in situ XRD measurements up to a temperature of $440{ }^{\circ} \mathrm{C}$ (see Figure 3). The lattice parameters and crystallite sizes of the pure $\mathrm{Mn}_{3} \mathrm{O}_{4}$ samples obtained by calcination in $\mathrm{Ar}$ as well as $\mathrm{O}_{2}$ atmospheres at $320^{\circ} \mathrm{C}$ and $350{ }^{\circ} \mathrm{C}$ listed in Table 1 are obviously independent of the calcination temperature, but dependent on the calcination atmosphere. The samples obtained in Ar exhibit crystallite sizes of less than a third compared to those obtained in $\mathrm{O}_{2}$. Furthermore, the lattice constants of $\mathrm{Mn}_{3} \mathrm{O}_{4}$ produced in Ar are smaller at all temperatures than those obtained by calcination in $\mathrm{O}_{2}$ atmosphere. This could be due to oxygen vacancies, as the oxygen for the oxidation to $\mathrm{Mn}_{3} \mathrm{O}_{4}$ in pure $\mathrm{Ar}$ is only supplied by the manganese glycolate precursor and cannot be obtained from the gas atmosphere. The presence of oxygen vacancies is also supported by the less pronounced variation of the lattice constants of $\mathrm{Mn}_{3} \mathrm{O}_{4}$ obtained at $320^{\circ} \mathrm{C}$ and $350{ }^{\circ} \mathrm{C}$ in $\mathrm{O}_{2}$ atmospheres, leading to the assumption of completely occupied oxygen sites in the structure of the oxide.

Cubic $\alpha-\mathrm{Mn}_{2} \mathrm{O}_{3}$ (ICDD 00-041-1442, Ia $\overline{3}$ ) is obtained in $\mathrm{Ar}$ after calcination at temperatures between 450 and $550{ }^{\circ} \mathrm{C}$ and at $500-550{ }^{\circ} \mathrm{C}$ in $\mathrm{O}_{2}$. Pure-phase $\alpha-\mathrm{Mn}_{2} \mathrm{O}_{3}$, however, is only obtained after calcination at temperatures of 500 and $550{ }^{\circ} \mathrm{C}$ in Ar and at $550{ }^{\circ} \mathrm{C}$ in $\mathrm{O}_{2}$ atmospheres (see also Table 1). The presence of $\alpha-\mathrm{Mn}_{2} \mathrm{O}_{3}$ after calcination at $500{ }^{\circ} \mathrm{C}$ in $\mathrm{O}_{2}$ does not support the observations made in the in situ XRD measurements (compare to Figure 3), where a generation of $\alpha-\mathrm{Mn}_{2} \mathrm{O}_{3}$ from $\mathrm{Mn}_{5} \mathrm{O}_{8}$ in an $\mathrm{O}_{2}$ atmosphere was only detected at temperatures above $530{ }^{\circ} \mathrm{C}$. However, this is probably due to an additional time dependence of the phase transformation of $\mathrm{Mn}_{5} \mathrm{O}_{8}$ to $\alpha-\mathrm{Mn}_{2} \mathrm{O}_{3}$, which was also suggested by Dimesso et al. [28]. In their report the $\alpha-\mathrm{Mn}_{2} \mathrm{O}_{3}$ phase was observed to be the minor species second to $\mathrm{Mn}_{5} \mathrm{O}_{8}$ after calcination at $400{ }^{\circ} \mathrm{C}$ in air for $1 \mathrm{~h}$, but was found to be the major species after calcination for $5 \mathrm{~h}$ at the same temperature. The lattice constants of the pure $\alpha-\mathrm{Mn}_{2} \mathrm{O}_{3}$ phase obtained after calcination in $\mathrm{Ar}$ and $\mathrm{O}_{2}$, are obviously independent of the temperature and the calcination atmosphere (see Table 1). Therefore, in contrast to the observations made for $\mathrm{Mn}_{3} \mathrm{O}_{4}$, the absence of $\mathrm{O}_{2}$ in the calcination atmosphere does not lead to an increase in the concentration of oxygen vacancies in the $\alpha-\mathrm{Mn}_{2} \mathrm{O}_{3}$ structure, which would be high enough to significantly change the lattice constants. The values of the Scherrer-derived crystallite sizes, however, suggest a temperature dependence of the obtained $\alpha-\mathrm{Mn}_{2} \mathrm{O}_{3}$ particle size in Ar atmosphere, which was not the case for the $\mathrm{Mn}_{3} \mathrm{O}_{4}$ particles. The Scherrer-derived size of the crystallites of the pure phase $\alpha-\mathrm{Mn}_{2} \mathrm{O}_{3}$ obtained in an $\mathrm{O}_{2}$ atmosphere at $550{ }^{\circ} \mathrm{C}$ is one third larger than that calculated for particles obtained in Ar at the same temperature. Hence, similar to the $\mathrm{Mn}_{3} \mathrm{O}_{4}$ phases described above, the presence of $\mathrm{O}_{2}$ in the calcination atmosphere yields larger crystallites of the same product.

No pure phase of monoclinic $\mathrm{Mn}_{5} \mathrm{O}_{8}$ (ICDD 00-039-1218, $\mathrm{C} 2 / \mathrm{m}$ ) could be obtained by calcination at temperatures between 320 and $550{ }^{\circ} \mathrm{C}$ for $2 \mathrm{~h}$ in both atmospheres. However, after calcination in $\mathrm{O}_{2}$ atmosphere, a small fraction of $\mathrm{Mn}_{5} \mathrm{O}_{8}$ can be detected in the products obtained at 400 and $450{ }^{\circ} \mathrm{C}$, while it forms the majority of the product obtained after calcination at $500{ }^{\circ} \mathrm{C}$. This is in good agreement with the in situ XRD patterns recorded in $\mathrm{O}_{2}$ atmosphere, where $\mathrm{Mn}_{5} \mathrm{O}_{8}$ was generated at about $350{ }^{\circ} \mathrm{C}$ and decomposed at $550{ }^{\circ} \mathrm{C}$ (see Figure 3 ).

In order to obtain pure-phase $\mathrm{Mn}_{5} \mathrm{O}_{8}$ particles, a longer calcination time of $5 \mathrm{~h}$ at $400{ }^{\circ} \mathrm{C}$ in an $\mathrm{O}_{2}$ atmosphere was chosen based on the time profile from the in situ XRD measurements (see Supporting Information File 1 for further details). 


\begin{tabular}{|c|c|c|c|c|}
\hline Temperature $\left[{ }^{\circ} \mathrm{C}\right]$ & Atmosphere & Crystalline phase(s) & Lattice parameters $[\AA]$ & Crystallite size $[\mathrm{nm}]$ \\
\hline \multirow[t]{2}{*}{320} & $\mathrm{Ar}$ & $\mathrm{Mn}_{3} \mathrm{O}_{4}$ & $\begin{array}{l}a=5.72 \\
c=9.38\end{array}$ & $11 \pm 3$ \\
\hline & $\mathrm{O}_{2}$ & $\mathrm{Mn}_{3} \mathrm{O}_{4}$ & $\begin{array}{l}a=5.75 \\
c=9.47\end{array}$ & $38 \pm 11$ \\
\hline \multirow[t]{2}{*}{350} & $\mathrm{Ar}$ & $\mathrm{Mn}_{3} \mathrm{O}_{4}$ & $\begin{array}{l}a=5.69 \\
c=9.44\end{array}$ & $10 \pm 3$ \\
\hline & $\mathrm{O}_{2}$ & $\mathrm{Mn}_{3} \mathrm{O}_{4}$ & $\begin{array}{l}a=5.74 \\
c=9.47\end{array}$ & $35 \pm 10$ \\
\hline \multirow[t]{2}{*}{400} & $\mathrm{Ar}$ & $\mathrm{Mn}_{3} \mathrm{O}_{4}$ & $\begin{array}{l}a=5.73 \\
c=9.39\end{array}$ & $9 \pm 2$ \\
\hline & $\mathrm{O}_{2}$ & $\mathrm{Mn}_{3} \mathrm{O}_{4}, \mathrm{Mn}_{5} \mathrm{O}_{8}$ & & \\
\hline \multirow[t]{2}{*}{450} & $\mathrm{Ar}$ & $\mathrm{a}-\mathrm{Mn}_{2} \mathrm{O}_{3}, \mathrm{Mn}_{3} \mathrm{O}_{4}$ & & \\
\hline & $\mathrm{O}_{2}$ & $\mathrm{Mn}_{3} \mathrm{O}_{4}, \mathrm{Mn}_{5} \mathrm{O}_{8}$ & & \\
\hline \multirow[t]{2}{*}{500} & $\mathrm{Ar}$ & $\mathrm{a}-\mathrm{Mn}_{2} \mathrm{O}_{3}$ & $a=9.41$ & $27 \pm 4$ \\
\hline & $\mathrm{O}_{2}$ & $\mathrm{Mn}_{5} \mathrm{O}_{8}, \alpha-\mathrm{Mn}_{2} \mathrm{O}_{3}$ & & \\
\hline \multirow[t]{2}{*}{550} & $\mathrm{Ar}$ & $\mathrm{a}-\mathrm{Mn}_{2} \mathrm{O}_{3}$ & $a=9.40$ & $34 \pm 5$ \\
\hline & $\mathrm{O}_{2}$ & $\mathrm{a}-\mathrm{Mn}_{2} \mathrm{O}_{3}$ & $a=9.41$ & $44 \pm 12$ \\
\hline
\end{tabular}

The properties of the $\mathrm{Mn}_{5} \mathrm{O}_{8}$ sample were investigated in more detail and compared to those of the $\mathrm{Mn}_{3} \mathrm{O}_{4}$ and $\alpha-\mathrm{Mn}_{2} \mathrm{O}_{3}$ samples obtained by calcination for $2 \mathrm{~h}$ in $\mathrm{Ar}$ at $350{ }^{\circ} \mathrm{C}$ and at $550{ }^{\circ} \mathrm{C}$, respectively. These $\mathrm{Mn}_{3} \mathrm{O}_{4}$ and $\alpha-\mathrm{Mn}_{2} \mathrm{O}_{3}$ samples were chosen as they exhibit the most interesting properties for possible catalytic applications due to their small particle sizes.

The X-ray diffraction pattern of pure $\mathrm{Mn}_{5} \mathrm{O}_{8}$ obtained by calcination in an $\mathrm{O}_{2}$ atmosphere at $400{ }^{\circ} \mathrm{C}$ for $5 \mathrm{~h}$ is shown in Figure 5. The Scherrer-derived crystallite size of this species is $22 \pm 5 \mathrm{~nm}$, and the lattice parameters of the monoclinic unit cell (ICDD 00-039-1218) are $a=10.40 \AA, b=5.73 \AA$ and $c=4.87 \AA$ with $\beta=109.6^{\circ}$, which is in good agreement with the data from literature $(a=10.34 \AA, b=5.72 \AA$ and $c=4.85 \AA$ with $\left.\beta=109.25^{\circ}\right)$ [31].

The temperature- and gas atmosphere-dependent oxidation process of $\mathrm{Mn}$ (II) glycolate to the manganese oxide species observed in the XRD patterns (see Figure 3 and Figure 4) was also investigated by thermogravimetric analysis (TGA). TGA measurements were recorded while heating the $\mathrm{Mn}(\mathrm{II})$ glycolate samples up to $700{ }^{\circ} \mathrm{C}$ with a heating rate of $2 \mathrm{~K} / \mathrm{min}$ in an $\mathrm{Ar}$ (black) and an $\mathrm{O}_{2} / \mathrm{Ar}$ (1:2) (red) flow, respectively.

In both atmospheres a mass loss of $2.1 \%$ due to loss of water from the samples is detected up to a temperature of $150{ }^{\circ} \mathrm{C}$. In Ar atmosphere, a further mass loss of $5.7 \%$ occurs up to $320^{\circ} \mathrm{C}$, which we attribute to the decomposition of the organic ligands

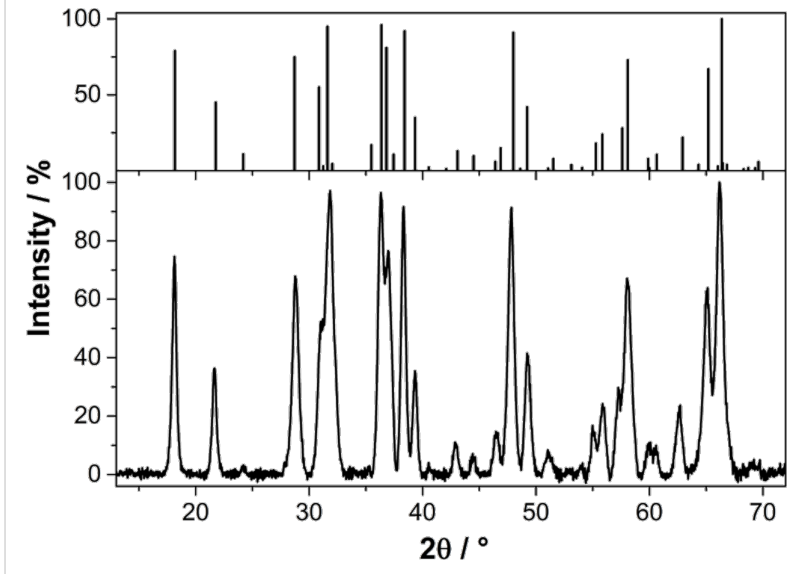

Figure 5: Powder XRD patterns of the $\mathrm{Mn}_{5} \mathrm{O}_{8}$ particles obtained by calcination of $\mathrm{Mn}$ (II) glycolate for $5 \mathrm{~h}$ at $400{ }^{\circ} \mathrm{C}$ in an $\mathrm{O}_{2}$ flow of $50 \mathrm{NL} / \mathrm{h}$; a reference pattern is given in the top panel (ICDD 00-0391218).

(tetraethylene glycol and ethylene glycol), whose boiling points are in the temperature range of $150{ }^{\circ} \mathrm{C}$ to $320^{\circ} \mathrm{C}$. Subsequently, a mass loss of about $37 \%$ is detected up to $450{ }^{\circ} \mathrm{C}$, which was also observed in TGA measurements of $\mathrm{Ti}(\mathrm{IV})$ glycolate by Jiang et al. [38] and was explained as a complete decomposition of the organic anions connecting the metal ions in that compound. Simultaneously, $\mathrm{Mn}(\mathrm{II})$ glycolate is oxidized to $\mathrm{Mn}_{3} \mathrm{O}_{4}$ and further to $\alpha-\mathrm{Mn}_{2} \mathrm{O}_{3}$ between $185^{\circ} \mathrm{C}$ to $450{ }^{\circ} \mathrm{C}$, as was observed in the XRD measurements after calcination of the precursor for $2 \mathrm{~h}$, as discussed above (see Figure 4). Although this oxidation process is accompanied by a decomposition of 
the organic groups, XPS results showed the presence of approximately 25 atom $\%$ carbon in the $\alpha-\mathrm{Mn}_{2} \mathrm{O}_{3}$ species obtained after calcination for $2 \mathrm{~h}$ at $550{ }^{\circ} \mathrm{C}$ in $\mathrm{Ar}$ atmosphere. This, however, will not have a significant effect on its application as an electrocatalyst, as the reference and substrate material for the catalysts consists of carbon.

The decomposition of the organic species of $\mathrm{Mn}(\mathrm{II})$ glycolate in combination with an immediate oxidation to $\mathrm{Mn}_{3} \mathrm{O}_{4}$ in $\mathrm{O}_{2}$ atmosphere was observed at $185{ }^{\circ} \mathrm{C}$ in the in situ XRD measurement depicted in Figure 3. In the TGA measurement, however, a mass loss of $44 \%$ attributed to this process is detected between 150 and $250{ }^{\circ} \mathrm{C}$. Hence, the observed mass loss includes the decomposition of organic species as well as the oxidation to $\mathrm{Mn}_{3} \mathrm{O}_{4}$. The temperature delay of the processes can be explained by considering the smaller $\mathrm{O}_{2}$ partial pressure of the atmosphere used for the TGA measurement. As both processes take place simultaneously, a clear assignment of the weight loss cannot be made. In order to investigate the processes subsequent to the large mass loss in the $\mathrm{O}_{2}$-containing atmosphere, a detailed view of the temperature region from 250 to $500{ }^{\circ} \mathrm{C}$ is shown in Figure 6b. Here, a mass increase of $0.54 \%$ is observed between 250 and $330{ }^{\circ} \mathrm{C}$ accompanied by a differential scanning calorimetry (DSC) signal of an exothermal phase transformation at $270{ }^{\circ} \mathrm{C}$ indicating a partial oxidation of $\mathrm{Mn}_{3} \mathrm{O}_{4}$ to $\mathrm{Mn}_{5} \mathrm{O}_{8}$. This is in good agreement with the development of the $\mathrm{Mn}_{5} \mathrm{O}_{8}$ phase observed at about $350{ }^{\circ} \mathrm{C}$ in the in situ XRD measurements (see Figure 3 ). The expected mass gain by complete oxidation to $\mathrm{Mn}_{5} \mathrm{O}_{8}$ of $5.59 \%$ is, however, much larger. Gillot et al. [27] proposed that heating rates between 1.2 and $2.5 \mathrm{~K} / \mathrm{min}$ could lead to a direct oxidation of $\mathrm{Mn}_{3} \mathrm{O}_{4}$ to $\alpha-\mathrm{Mn}_{2} \mathrm{O}_{3}$ even in $\mathrm{O}_{2}$ atmosphere, which would result in an expected mass gain of $0.97 \%$. As both the direct oxidation of $\mathrm{Mn}_{3} \mathrm{O}_{4}$ to $\alpha-\mathrm{Mn}_{2} \mathrm{O}_{3}$ and the oxidation via $\mathrm{Mn}_{5} \mathrm{O}_{8}$ would result in larger mass increases than the one observed in the measurement $(0.54 \%)$, it is suggested that the decomposition of the organic species is not complete at a temperature of $330^{\circ} \mathrm{C}$. However, the subsequent mass loss of $1.60 \%$ from 330 to $480{ }^{\circ} \mathrm{C}$, a DSC signal of an exothermal phase transformation at $480{ }^{\circ} \mathrm{C}$, and the XRD measurements presented in this report (see Figure 3 and Figure 4) indicate the presence of $\mathrm{Mn}_{5} \mathrm{O}_{8}$. This mass loss again is lower than the expected value of $2.03 \%$ for a complete conversion of $\mathrm{Mn}_{5} \mathrm{O}_{8}$ to $\alpha-\mathrm{Mn}_{2} \mathrm{O}_{3}$, which indicates that less $\alpha-\mathrm{Mn}_{2} \mathrm{O}_{3}$ is formed from $\mathrm{Mn}_{5} \mathrm{O}_{8}$ than expected. Hence, in an $\mathrm{O}_{2} / \mathrm{Ar}$ atmosphere, $\alpha-\mathrm{Mn}_{2} \mathrm{O}_{3}$ is generated partially from $\mathrm{Mn}_{5} \mathrm{O}_{8}$ and partially by direct oxidation from $\mathrm{Mn}_{3} \mathrm{O}_{4}$.

The increase and decrease in mass in the presence of gaseous $\mathrm{O}_{2}$ was proposed to be due to slow seed crystal oxidation of $\mathrm{Mn}_{3} \mathrm{O}_{4}$ to $\mathrm{Mn}_{5} \mathrm{O}_{8}$ for particles with BET surfaces larger than

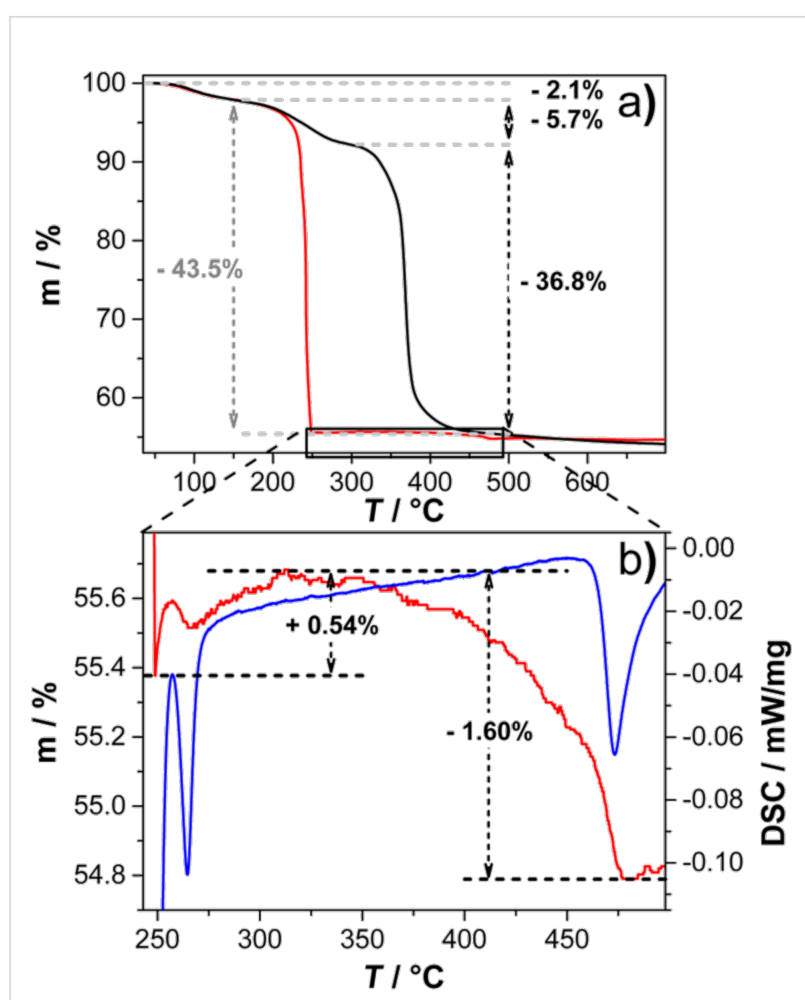

Figure 6: a) TGA measurements recorded while heating the $\mathrm{Mn}(\mathrm{II})$ glycolate precursor up to $700^{\circ} \mathrm{C}$ at $2 \mathrm{~K} / \mathrm{min}$ in an $\mathrm{Ar}$ (black) and an $\mathrm{O}_{2} / \mathrm{Ar}(1: 2)$ (red) flow of $40 \mathrm{NmL} / \mathrm{min}$; b) detailed view of the temperature range between 250 and $500{ }^{\circ} \mathrm{C}$ of the TGA (red) and DSC (blue) measurements in $\mathrm{O}_{2} / \mathrm{Ar}(1: 2)$ flow indicating the oxidation of $\mathrm{Mn}_{3} \mathrm{O}_{4}$ to $\mathrm{Mn}_{5} \mathrm{O}_{8}$ and $\alpha-\mathrm{Mn}_{2} \mathrm{O}_{3}$.

$10 \mathrm{~m}^{2} / \mathrm{g}$ and their subsequent transformation to $\alpha-\mathrm{Mn}_{2} \mathrm{O}_{3}$ [29,30].

In order to characterize the size of the particles and the active surface areas, pure $\mathrm{Mn}_{3} \mathrm{O}_{4}, \mathrm{Mn}_{5} \mathrm{O}_{8}$ and $\alpha-\mathrm{Mn}_{2} \mathrm{O}_{3}$ species obtained by calcination of the $\mathrm{Mn}$ (II) glycolate precursor at temperatures of 350,400 and $550{ }^{\circ} \mathrm{C}$ were characterized by TEM and BET measurements. The TEM images of the $\mathrm{Mn}_{3} \mathrm{O}_{4}$ and $\mathrm{Mn}_{5} \mathrm{O}_{8}$ samples are shown in Figure 7a,b; the sizes of the particles observed in TEM are in good agreement with the Scherrer-derived crystallite sizes calculated from the XRD patterns (see Figure 4 for comparison). The $\mathrm{Mn}_{3} \mathrm{O}_{4}$ sample shown in Figure 7 a consists of a network of nanoparticles with diameters less than $10 \mathrm{~nm}$ and voids between the particles of about the same size. The same is true for the $\mathrm{Mn}_{5} \mathrm{O}_{8}$ sample in Figure $7 \mathrm{~b}$, but here the nanoparticles with diameters of up to $30 \mathrm{~nm}$ are obviously packed more densely. We attribute this to the increased temperature and duration of the calcination process, as well as to the presence of $\mathrm{O}_{2}$ in the atmosphere, which leads to larger particles, as previously discussed (see discussion for Figure 4). The $\alpha-\mathrm{Mn}_{2} \mathrm{O}_{3}$ sample obtained by calcination in an Ar atmosphere (see Figure 7c,d), however, 
contains splinter-like pieces in the $\mu \mathrm{m}$ range (approximately $1-2 \mu \mathrm{m}$ in the given TEM image) with a high concentration of holes with diameters of up to $20 \mathrm{~nm}$, rather than individual nanoparticles. This manner of porosity for $\alpha-\mathrm{Mn}_{2} \mathrm{O}_{3}$ was also confirmed by $\mathrm{N}_{2}$ adsorption-desorption measurements (see Figure 8). Mesoporosity in hexagonally shaped $\alpha-\mathrm{Mn}_{2} \mathrm{O}_{3}$ particles and circular $\mathrm{Mn}_{2} \mathrm{O}_{3}$ discs obtained by calcination at temperatures above $600{ }^{\circ} \mathrm{C}$ was reported by several groups $[17,37]$. Ren et al. suggested that the mesopores are derived from a sequence of processes including $\mathrm{Mn}_{5} \mathrm{O}_{8}$ nanoparticle growth, rearrangement and merging during the transformation to $\alpha-\mathrm{Mn}_{2} \mathrm{O}_{3}$ [37]. As the phase of $\mathrm{Mn}_{5} \mathrm{O}_{8}$ was not observed after calcination in Ar atmosphere, we propose that the presence of pores in the $\alpha-\mathrm{Mn}_{2} \mathrm{O}_{3}$ particles reported here results from the analog growth, rearrangement and merging processes of the $\mathrm{Mn}_{3} \mathrm{O}_{4}$ nanoparticles.
The considerably smaller size of the crystallites obtained from the broadening of the XRD reflections of $\alpha-\mathrm{Mn}_{2} \mathrm{O}_{3}$ is another argument for the porosity of these particles, as the pore walls in this case represent boundaries of the crystalline domains. Because these domains are regarded as Scherrer crystallites, we conclude that the obtained sizes are the mean distances between the pores as well as the minimum diameter of the $\alpha-\mathrm{Mn}_{2} \mathrm{O}_{3}$ particles.

From the isotherms recorded during $\mathrm{N}_{2}$ adsorption-desorption measurements (see Figure $8 \mathrm{a}$ ) specific BET surface areas of 302,30 and $20 \mathrm{~m}^{2} / \mathrm{g}$ were calculated for the $\mathrm{Mn}_{3} \mathrm{O}_{4}, \mathrm{Mn}_{5} \mathrm{O}_{8}$ and $\alpha-\mathrm{Mn}_{2} \mathrm{O}_{3}$ samples, respectively. The porosity of the $\alpha-\mathrm{Mn}_{2} \mathrm{O}_{3}$ particles observed in the TEM images (see Figure $7 \mathrm{c}, \mathrm{d}$ ) is also supported by the $\mathrm{N}_{2}$ adsorption-desorption isotherms, which exhibit hysteresis. As hysteresis is also

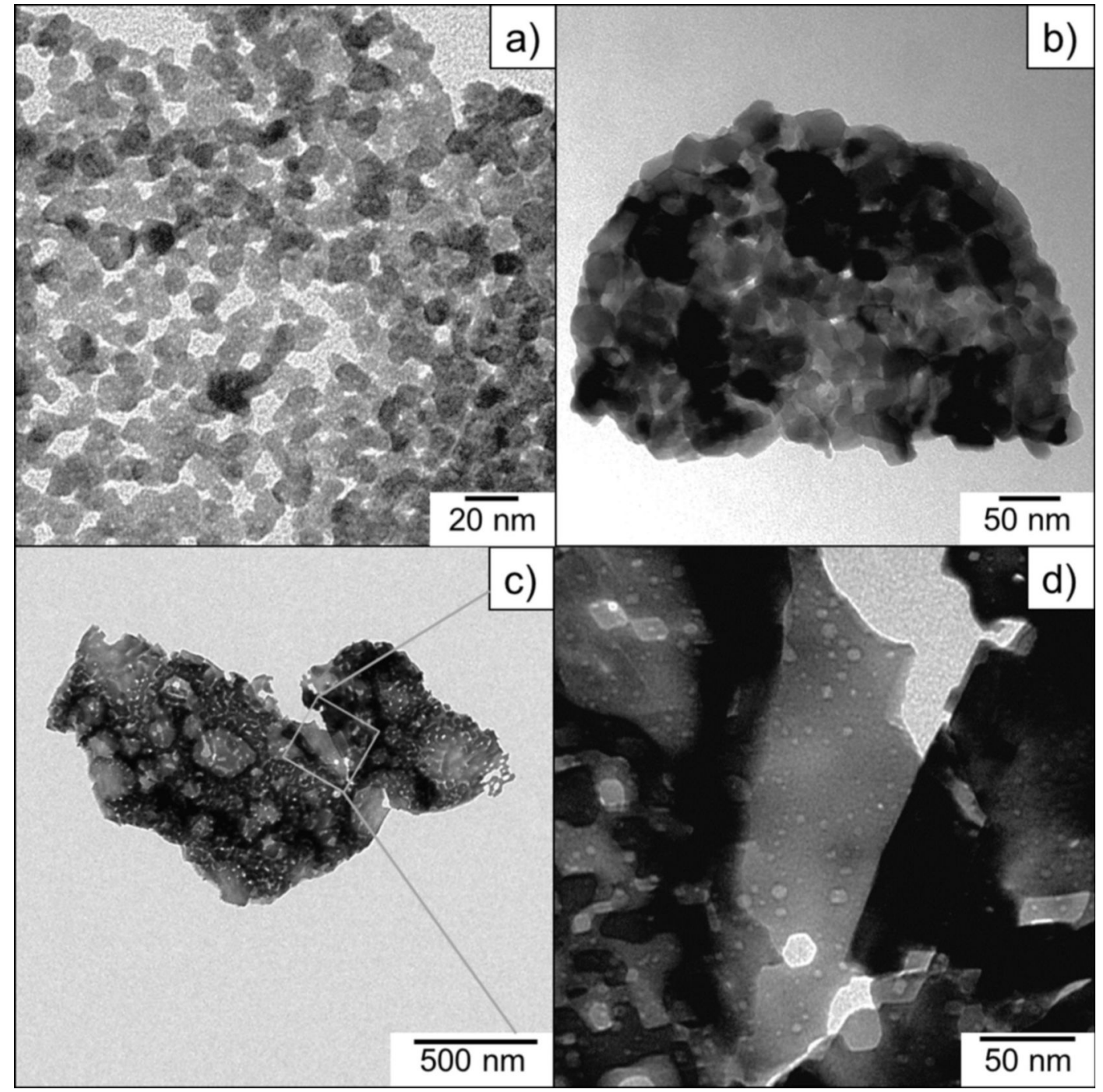

Figure 7: TEM images of the a) $\mathrm{Mn}_{3} \mathrm{O}_{4}$, b) $\mathrm{Mn}_{5} \mathrm{O}_{8}$, and c) and d) $\alpha-\mathrm{Mn}_{2} \mathrm{O}_{3}$ samples. 

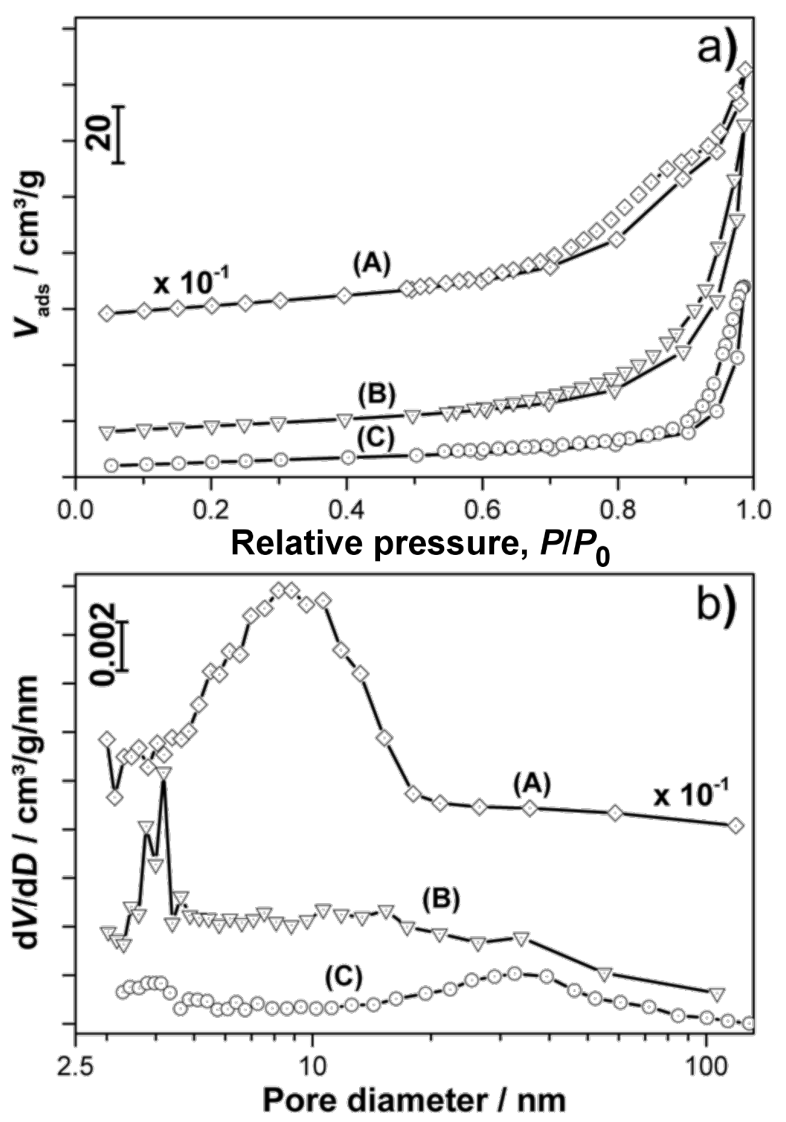

Figure 8: a) $\mathrm{N}_{2}$ adsorption-desorption isotherms (volume adsorbed versus relative pressure, $P\left(P_{0}\right)$ and $b$ ) the corresponding pore size distributions of the (A) $\mathrm{Mn}_{3} \mathrm{O}_{4},(B) \mathrm{Mn}_{5} \mathrm{O}_{8}$ and (C) $\alpha-\mathrm{Mn}_{2} \mathrm{O}_{3}$ samples.

observed in the $\mathrm{Mn}_{3} \mathrm{O}_{4}$ and $\mathrm{Mn}_{5} \mathrm{O}_{8}$ nanoparticle isotherms (but not supported by observations made in the TEM images for these species, see Figure 7a,b), two different definitions of porosity can be applied for the different manganese oxide species. The pore size distributions depicted in Figure $8 \mathrm{~b}$ show a pore diameter distribution between 3 and $20 \mathrm{~nm}$ with a mean pore diameter of $8.2 \mathrm{~nm}$ for the $\mathrm{Mn}_{3} \mathrm{O}_{4}$ sample. The porosity of the $\mathrm{Mn}_{3} \mathrm{O}_{4}$ nanoparticles can be explained by considering the voids between the particles in the network as the "pores" detected in the $\mathrm{N}_{2}$ adsorption-desorption measurements. This assumption is in good agreement with the similar sizes of the voids and nanoparticles observed in the TEM image (compared with Figure 7a). The same "pore definition" can be applied to the $\mathrm{Mn}_{5} \mathrm{O}_{8}$ sample exhibiting pore sizes between 3 and $5 \mathrm{~nm}$ with a comparably small mean pore size of $4.2 \mathrm{~nm}$, probably due to the dense network of the particles observed in the TEM image (compared to Figure 7b). The $\alpha-\mathrm{Mn}_{2} \mathrm{O}_{3}$ sample does not contain nanoparticles, but exhibits a pore size distribution between 3 and $5 \mathrm{~nm}$ as well as 10 and $90 \mathrm{~nm}$ with a mean diameter of $32.6 \mathrm{~nm}$. In accordance with the TEM images (see
Figure 7c,d for comparison) and the lowest BET surface area of all the samples, these pores do not derive from voids in the nanoparticle network but rather from the mesoporosity of the splinter-like pieces. A surface area of approximately $20 \mathrm{~m}^{2} / \mathrm{g}$ and pore diameters from 4 to $7 \mathrm{~nm}$ were also reported for $\mathrm{Mn}_{2} \mathrm{O}_{3}$ discs synthesized for the use as electrode material by Zhang et al. [17]. However, we believe a larger pore size to be advantageous for application as electrocatalysts, as electrochemical processes often produce solid products, which might easily clog pores in the micro- and meso-porous range.

The specific surface areas of $\mathrm{Mn}_{3} \mathrm{O}_{4}$ and $\mathrm{Mn}_{5} \mathrm{O}_{8}$ are in good agreement with the sizes of the particles observed in the TEM images and calculated from the XRD patterns, as smaller particles generally exhibit larger surface areas. However, the $\alpha-\mathrm{Mn}_{2} \mathrm{O}_{3}$ particles, which are one order of magnitude larger, exhibit a high specific BET surface area comparable to that of the $\mathrm{Mn}_{5} \mathrm{O}_{8}$ nanoparticles. Two explanations for this large specific surface are proposed: the lower molar weight of $\alpha-\mathrm{Mn}_{2} \mathrm{O}_{3}$ compared to $\mathrm{Mn}_{5} \mathrm{O}_{8}$ (resulting in a larger specific surface area), and the mesoporosity of the $\alpha-\mathrm{Mn}_{2} \mathrm{O}_{3}$, which was already observed in the TEM images (see Figure 7c,d).

\section{Electrocatalytic activities of the $\mathrm{MnO}_{x}$ species}

In order to investigate the electrocatalytic activity of the synthesized $\mathrm{MnO}_{x}$ species for the oxygen reduction reaction (ORR), linear sweep measurements were carried out.

Figure 9 shows linear sweep measurements recorded at $50 \mathrm{mV} / \mathrm{s}$ comparing the activity of various $10 \% \mathrm{MnO}_{x}$ /carbon electrodes to a pure carbon electrode as a reference material for the ORR in aprotic electrolyte. The ORR peak potentials as well as the apparent reaction rate constant, $k_{\text {app }}^{0}$, for the different electrode materials are summarized in Table 2 . The reaction rate constant was calculated from:

$$
j_{0}=n \cdot F \cdot C_{\mathrm{O} 2} \cdot k_{\mathrm{app}}^{0},
$$

where $j_{0}$ is the cathodic exchange current density (obtained from the Tafel plots of the linear sweep measurements), $n=1$ is the number of transferred electrons, $F$ is the Faraday constant, and $C_{\mathrm{O} 2}=2.1 \cdot 10^{-6} \mathrm{~mol} \mathrm{~cm}^{-3}$ is the oxygen solubility in DMSO [39].

The mean ORR peak potential of the carbon reference material given in Table 2 is observed at $2.58 \mathrm{~V}$. The only $\mathrm{MnO}_{x}$ species with a significant increase of the ORR potential of $100 \mathrm{mV}$ with respect to the carbon as well as the other $\mathrm{MnO}_{x} / \mathrm{C}$ electrodes is the mesoporous $\alpha-\mathrm{Mn}_{2} \mathrm{O}_{3}$ catalyst. The obvious activity is 


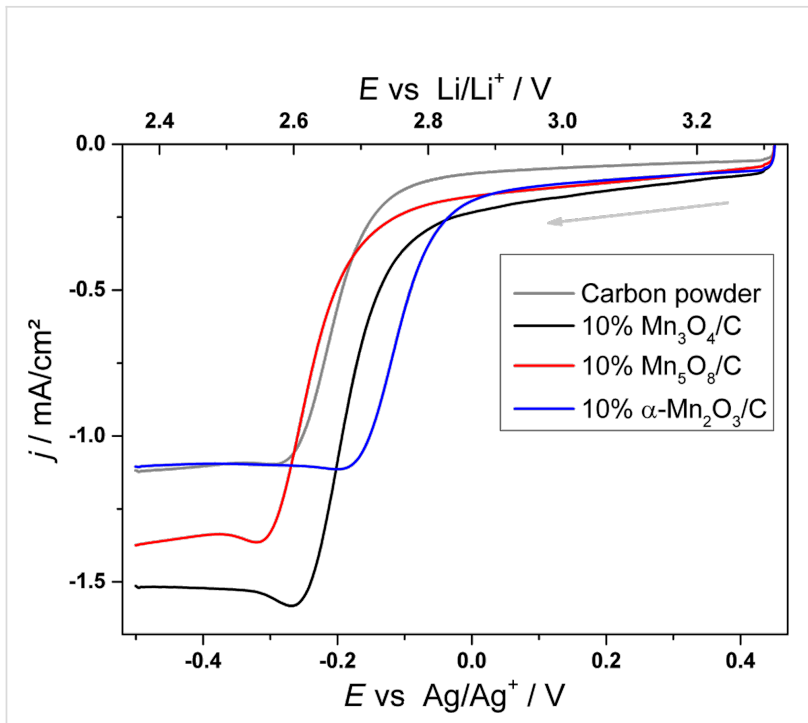

Figure 9: Linear sweep voltammograms of pure carbon powder (grey) $\mathrm{Mn}_{3} \mathrm{O}_{4} / \mathrm{C}$ (black), $\mathrm{Mn}_{5} \mathrm{O}_{8} / \mathrm{C}$ (red) and $\mathrm{\alpha}-\mathrm{Mn}_{2} \mathrm{O}_{3} / \mathrm{C}$ (blue) electrodes; electrolyte: $1 \mathrm{M} \mathrm{LiTFSI/DMSO}$, cathodic scan direction, $v=50 \mathrm{mV} / \mathrm{s}$, $\omega=200 \mathrm{rpm}$.

Table 2: ORR potentials and reaction rate constants obtained from the linear sweep measurements recorded at $\mathrm{v}=50 \mathrm{mV} / \mathrm{s}$.

\begin{tabular}{lll} 
& $E_{\text {peak }}$ vs Li/Li & $k_{\text {app }}^{0}\left[10^{-4} \mathrm{~cm} / \mathrm{s}\right]$ \\
\hline Carbon $(\mathrm{C})$ & $2.58 \pm 0.02$ & $1.2 \pm 1.1$ \\
$\mathrm{Mn}_{3} \mathrm{O}_{4} / \mathrm{C}$ & $2.58 \pm 0.08$ & $2.6 \pm 1.3$ \\
$\mathrm{Mn}_{5} \mathrm{O}_{8} / \mathrm{C}$ & $2.58 \pm 0.07$ & $2.7 \pm 2.3$ \\
$\alpha-\mathrm{Mn}_{2} \mathrm{O}_{3} / \mathrm{C}$ & $2.68 \pm 0.05$ & $4.5 \pm 2.5$
\end{tabular}

reflected in the approximately four- and two-fold larger apparent ORR rate constant $k_{\text {app }}^{0}$ compared to the carbon and the other $\mathrm{MnO}_{x} / \mathrm{C}$ electrodes, respectively.

A detailed kinetic and mechanistic study on the electrocatalytic activities of the different $\mathrm{MnO}_{x}$ species for the aprotic oxygen reduction reaction is reported elsewhere [40].

\section{Conclusion}

In summary, a polyol synthesis was presented yielding rectangular, Mn(II) glycolate nanoparticles with dimensions of $17 \pm 8 \mathrm{~nm}$. Particle sizes of less than $100 \mathrm{~nm}$ are reported here for the first time. We attribute this small size of the particles to the stabilizing tetraethylene glycol ligand used during the synthesis, as well as milder reaction conditions compared with other reports (i.e., a decreased temperature and a longer reaction time). In situ XRD measurements showed the sequence of time- and temperature-dependent phase transformations during oxidation of the $\mathrm{Mn}$ (II) glycolate precursor to $\alpha-\mathrm{Mn}_{2} \mathrm{O}_{3}$ via $\mathrm{Mn}_{3} \mathrm{O}_{4}$ and $\mathrm{Mn}_{5} \mathrm{O}_{8}$ in $\mathrm{O}_{2}$ atmosphere. Structural and morphological investigations revealed the dependence of the lattice constants and particle sizes of the $\mathrm{MnO}_{x}$ species on the calcination temperatures in a range from 320 to $550{ }^{\circ} \mathrm{C}$ as well as on $\mathrm{Ar}$ and $\mathrm{O}_{2}$ atmospheres. Based on the results of these measurements, several manganese oxide species were synthesized by calcination of $\mathrm{Mn}$ (II) glycolate particles in argon and oxygen atmosphere at different temperatures. The calcination process yielded $\mathrm{Mn}_{3} \mathrm{O}_{4}$ nanoparticles with dimensions of about $10 \mathrm{~nm}$ and a surface area of $302 \mathrm{~m}^{2} / \mathrm{g}, \mathrm{Mn}_{5} \mathrm{O}_{8}$ nanoparticles with diameters of $22 \mathrm{~nm}$ and a surface area of $30 \mathrm{~m}^{2} / \mathrm{g}$ as well as mesoporous $\alpha-\mathrm{Mn}_{2} \mathrm{O}_{3}$ particles with mean pore diameters of about $33 \mathrm{~nm}$ and a surface area of $20 \mathrm{~m}^{2} / \mathrm{g}$. The small dimensions of the particles and large surface areas of the manganese oxides presented here result from use of nanostructured precursor particles. Linear sweep measurements showed the activity of the mesoporous $\alpha-\mathrm{Mn}_{2} \mathrm{O}_{3}$ species for the oxygen reduction reaction in aprotic media with respect to the observed potentials as well as an enhanced kinetic activity. The catalytic activity of different manganese oxides can be enhanced by a larger surface area, resulting from small particle dimensions or mesoporosity. This makes our synthesis a suitable process to obtain manganese oxides having properties of particular interest for electrochemical and chemical catalysis. Furthermore, the synthesis of manganese oxides via one route reported here is of additional interest, as it excludes any synthesis-caused effects on the products and allows investigation on the catalytic effect of similarly synthesized manganese oxides with different properties.

\section{Experimental Materials}

Manganese(II) acetate tetrahydrate $\left(\mathrm{MnAc}_{2},>99 \%\right.$, pure) and ethylene glycol (EG, $>99.5 \%$, p.a.) were purchased from CarlRoth. Tetraethylene glycol (TEG, 99\%) was delivered by Sigma-Aldrich. For the electrode preparation, a 10 wt \% Nafion ${ }^{\circledR} /$ water solution was purchased from Sigma-Aldrich, analytical reagent-grade ethanol from Fisher Scientific, and Vulcan ${ }^{\circledR}$ XC72R carbon powder was obtained from Cabot. For electrochemical measurements, reagent-grade lithium bis(trifluoromethylsulfonyl)imide (LiTFSI) was purchased from Merck KGaA and dimethyl sulfoxide (DMSO, anhydrous, $\geq 99.9 \%$ ) from Sigma-Aldrich. All chemicals were used without further purification.

\section{Synthesis of $\mathrm{Mn}(\mathrm{II})$ glycolate}

In a typical reaction, $1 \mathrm{mmol}(0.246 \mathrm{~g}) \mathrm{MnAc}_{2}$ was mixed with $3 \mathrm{mmol}(3 \mathrm{~mL}$ ) TEG and added to $30 \mathrm{~mL}$ EG in a three-neck round-bottom flask. The solution was heated to $170{ }^{\circ} \mathrm{C}$ while stirring. Upon heating, the solution turned brown at a tempera- 
ture of about $110^{\circ} \mathrm{C}$, and after further heating for about $1 \mathrm{~h}$ at $170{ }^{\circ} \mathrm{C}$, a white precipitate appeared that disappeared again after $1 \mathrm{~h}$. The solution was stirred for another $4 \mathrm{~h}$ at $170{ }^{\circ} \mathrm{C}$ until a white precipitate appeared again which indicated the formation of the $\mathrm{Mn}(\mathrm{II})$ glycolate particles. The product was stirred for another hour at $170{ }^{\circ} \mathrm{C}$ to complete the reaction and was subsequently cooled down to room temperature. The white powder was centrifuged and washed at least five times with ethanol to remove any impurities. Subsequently, the white product was dried under Ar flow.

\section{Synthesis of $\mathrm{Mn}_{3} \mathrm{O}_{4}, \mathrm{Mn}_{5} \mathrm{O}_{8}$ and $\alpha-\mathrm{Mn}_{2} \mathrm{O}_{3}$}

The obtained $\mathrm{Mn}$ (II) glycolate powder was calcined in an $\mathrm{Ar}$ flow of $50 \mathrm{NL} / \mathrm{h}$ for $2 \mathrm{~h}$ at $350{ }^{\circ} \mathrm{C}$ and at $550{ }^{\circ} \mathrm{C}$ yielding $\mathrm{Mn}_{3} \mathrm{O}_{4}$ and $\alpha-\mathrm{Mn}_{2} \mathrm{O}_{3}$, respectively. $\mathrm{Mn}_{5} \mathrm{O}_{8}$ was obtained by calcination of the precursor in an $\mathrm{O}_{2}$ flow of $50 \mathrm{NL} / \mathrm{h}$ for $5 \mathrm{~h}$ at $400{ }^{\circ} \mathrm{C}$.

\section{Characterization methods}

Transmission electron microscopy (TEM) was carried out with a Zeiss EM 902A microscope with an acceleration voltage of $80 \mathrm{kV}$. For high resolution TEM (HR-TEM) measurements a JEOL JEM2100F microscope with an acceleration voltage of $200 \mathrm{kV}$ was used. The samples for TEM and HR-TEM measurements were prepared by depositing a drop of an ethanol emulsion of the powder on a carbon-coated copper grid and drying at room temperature.

Scanning electron microscopy (SEM) was carried out with an Oxford INCA system employing a PentaFET Precision INCA $\mathrm{X}$-act detector integrated into the Hitchai S-3200N microscope. The sample was prepared by depositing an ethanol emulsion of the sample onto an Al substrate and drying at room temperature.

For X-ray diffraction (XRD), a PANalytical X'Pert Pro MPD diffractometer was used operating with $\mathrm{Cu} \mathrm{K} \alpha$ radiation, BraggBrentano $\theta-2 \theta$ geometry and a goniometer radius of $240 \mathrm{~mm}$. Samples for XRD measurements were prepared by placing the powder onto low-background silicon sample holders. Different atmospheres were used as mentioned in the text. The crystallite sizes of the samples were calculated from all assigned reflections via the Scherrer equation. The lattice parameters were obtained with the Bragg equation from assigned diffraction reflections.

In situ XRD measurements were performed in the same geometry using a high temperature chamber from Anton Paar (HTK $1200 \mathrm{~N})$. The temperature profile measurement was recorded while heating the powder sample from 25 to $700{ }^{\circ} \mathrm{C}$ with a heating rate of $2 \mathrm{~K} / \mathrm{min}$. The time profile measurement (shown in Supporting Information File 1) was conducted by heating the powder sample from 25 to $400{ }^{\circ} \mathrm{C}$ with a heating rate of $18 \mathrm{~K} / \mathrm{min}$ and subsequent constant heating at $400{ }^{\circ} \mathrm{C}$ for $350 \mathrm{~min}$. The powder sample was placed on a corundum sample holder. During the measurement the thermal expansion was corrected automatically. The measurements were performed in an $\mathrm{O}_{2}$ flow.

Thermogravimetric analysis (TGA) and differential scanning calorimetry (DSC) were carried out with a Netzsch STA 449 F3 Jupiter thermo-analysis system. The sample was deposited in an $\mathrm{Al}_{2} \mathrm{O}_{3}$ crucible and heated from 35 to $700{ }^{\circ} \mathrm{C}$ with a heating rate of $2 \mathrm{~K} / \mathrm{min}$ in an $\mathrm{O}_{2}(6.0) / \operatorname{Ar}(5.0)(1: 2)$ and an $\operatorname{Ar}(5.0)$ gas flow of $40 \mathrm{NmL} / \mathrm{min}$.

The porosity of the manganese oxides was determined by $\mathrm{N}_{2}$ adsorption-desorption measurements. Prior to the measurement, the material was kept for $18 \mathrm{~h}$ at $180{ }^{\circ} \mathrm{C}$ under vacuum to remove any residual gas and moisture from the sample. The adsorption-desorption isotherms were measured employing a Quantachrome Nova $2000 \mathrm{E}$ device at $77 \mathrm{~K}$. The Brunauer-Emmet-Teller (BET) method was used to determine the complete inner surfaces $S_{0}$ and the Barrett-Joyner-Halenda (BJH) method for mesopore surface analysis as well as the determination of pore size distributions.

\section{Electrode preparation}

The catalyst/carbon ink for the powder electrodes was prepared by mixing and grinding $90 \mathrm{mg}$ Vulcan ${ }^{\circledR}$ XC72R carbon powder with $10 \mathrm{mg}$ of $\mathrm{MnO}_{x}$ catalyst. This active material was dispersed in ethanol and ultrasonicated for $20 \mathrm{~min}$. As a binder material, $0.1 \mathrm{wt} \% \mathrm{Nafion} /$ water solution was added to the catalyst/carbon paste and ultrasonicated for another $20 \mathrm{~min}$. A $10 \mu \mathrm{L}$ drop of the ink was applied on a glassy carbon disc $(d=0.5 \mathrm{~cm})$ and dried for $12 \mathrm{~h}$ at $80{ }^{\circ} \mathrm{C}$. The $10 \mathrm{wt} \%$ catalyst loading of the prepared electrodes equals $4.8 \mu \mathrm{g}$ per electrode or $24.4 \mu \mathrm{g} \mathrm{cm}^{-2}$.

\section{Electrochemical measurements}

For linear sweep voltammetry measurements, a Gamry Instruments Reference 600 Potentiostat was used. The measurements were carried out on a rotating disc electrode (RDE) in a glove box in Ar atmosphere at ambient temperature. For the electrochemical setup, glassy carbon (Pine Research Instrumentation, electrode model no. AFE3T050GC) and carbon/catalyst-coated glassy carbon discs (see above) served as working electrodes. A polished Ag wire and a Pt disc were used as reference and counter electrodes, respectively. $1 \mathrm{M}$ LiTFSI/DMSO was used as the electrolyte, which was saturated with pure $\mathrm{O}_{2}$ for $25 \mathrm{~min}$ before the start of the measurement. The linear sweep measurements were recorded at a scan rate of $v=50 \mathrm{mV} / \mathrm{s}$ and a rotational frequency of $\omega=200 \mathrm{rpm}$. 


\section{Supporting Information}

The supporting information features the powder XRD pattern of $\mathrm{Mn}(\mathrm{II})$ glycolate particles after $1 \mathrm{~h}$ of synthesis at $170{ }^{\circ} \mathrm{C}$ in addition to in situ XRD patterns of the time-dependent oxidation of $\mathrm{Mn}_{3} \mathrm{O}_{4}$ to $\mathrm{Mn}_{5} \mathrm{O}_{8}$ at $400{ }^{\circ} \mathrm{C}$ in $\mathrm{O}_{2}$.

\section{Supporting Information File 1}

Additional XRD experimental data.

[http://www.beilstein-journals.org/bjnano/content/ supplementary/2190-4286-6-6-S1.pdf]

\section{Acknowledgements}

We thank Magdalena Bogacka for conducting the TGA/DSC measurements. We gratefully acknowledge the funding of the EWE Research Group "Thin Film Photovoltaics" by the EWE AG, Oldenburg, Germany, as well as funding by the government of Lower Saxony (Germany).

\section{References}

1. Owens, B. B.; Passerini, S.; Smyrl, W. H. Electrochim. Acta 1999, 45, 215-224. doi:10.1016/S0013-4686(99)00205-4

2. Park, K.-W. J. Mater. Chem. A 2014, 2, 4292-4298. doi:10.1039/c3ta14223j

3. Xu, M.-W.; Niu, Y.-B.; Bao, S.-J.; Li, C. M. J. Mater. Chem. A 2014, 2, 3749-3755. doi:10.1039/c3ta14211f

4. Gil, A.; Gandía, L. M.; Korili, S. A. Appl. Catal., A 2004, 274, 229-235. doi:10.1016/j.apcata.2004.07.004

5. Mellan, T. A.; Maenetja, K. P.; Ngoepe, P. E.; Woodley, S. M.; Catlow, C. R. A.; Grau-Crespo, R. J. Mater. Chem. A 2013, 1 , 14879-14887. doi:10.1039/c3ta13559d

6. Feng, Q.; Kanoh, H.; Ooi, K. J. Mater. Chem. 1999, 9, 319-333. doi:10.1039/a805369c

7. Kapteljn, F.; Singoredjo, L.; Andreini, A.; Moulijn, J. A. Appl. Catal., B: Environ. 1994, 3, 173-189. doi:10.1016/0926-3373(93)E0034-9

8. Xiao, J.; Wan, L.; Wang, X.; Kuang, Q.; Dong, S.; Xiao, F.; Wang, S. J. Mater. Chem. A 2014, 2, 3794-3800. doi:10.1039/c3ta14453d

9. Su, H.-Y.; Gorlin, Y.; Man, I. C.; Calle-Vallejo, F.; Nørskov, J. K.; Jaramillo, T. F.; Rossmeisl, J. Phys. Chem. Chem. Phys. 2012, 14, 14010-14022. doi:10.1039/c2cp40841d

10. Ramírez, A.; Friedrich, D.; Kunst, M.; Fiechter, S. Chem. Phys. Lett. 2013, 568-569, 157-160. doi:10.1016/j.cplett.2013.03.054

11. Najafpour, M. M.; Rahimi, F.; Amini, M.; Nayeri, S.; Bagherzadeh, M. Dalton Trans. 2012, 41, 11026-11031. doi:10.1039/c2dt30553d

12. Ogasawara, T.; Débart, A.; Holzapfel, M.; Novák, P.; Bruce, P. G. J. Am. Chem. Soc. 2006, 128, 1390-1393. doi:10.1021/ja056811q

13. Débart, A.; Bao, J.; Armstrong, G.; Bruce, P. G. J. Power Sources 2007, 174, 1177-1182. doi:10.1016/j.jpowsour.2007.06.180

14. Giordani, V.; Freunberger, S. A.; Bruce, P. G.; Tarascon, J.-M.; Larcher, D. Electrochem. Solid-State Lett. 2010, 13, A180-A183. doi:10.1149/1.3494045

15. Cheng, H.; Scott, K. Appl. Catal., B: Environ. 2011, 108-109, 140-151. doi:10.1016/j.apcatb.2011.08.021
16. Jung, K.-N.; Riaz, A.; Lee, S.-B.; Lim, T.-H.; Park, S.-J.; Song, R.-H.; Yoon, S.; Shin, K.-H.; Lee, J.-W. J. Power Sources 2013, 244, 328-335. doi:10.1016/j.jpowsour.2013.01.028

17. Zhang, Y.; Yan, Y.; Wang, X.; Li, G.; Deng, D.; Jiang, L.; Shu, C.; Wang, C. Chem. - Eur. J. 2014, 22, 6126-6130. doi:10.1002/chem.201304935

18. Lei, S.; Tang, K.; Fang, Z.; Liu, Q.; Zheng, H. Mater. Lett. 2006, 60, 53-56. doi:10.1016/j.matlet.2005.07.070

19. Liu, L.; Yang, Z.; Liang, H.; Yang, H.; Yang, Y. Mater. Lett. 2010, 64, 891-893. doi:10.1016/j.matlet.2010.01.054

20. Azzoni, C. B.; Mozzati, M. C.; Galinetto, P.; Paleari, A.; Massarotti, V.; Capsoni, D.; Bini, M. Solid State Commun. 1999, 112, 375-378. doi:10.1016/S0038-1098(99)00368-3

21. Cushing, B. L.; Kolesnichenko, V. L.; O'Connor, C. J. Chem. Rev. 2004, 104, 3893-3946. doi:10.1021/cr030027b

22. Gui, Z.; Fan, R.; Mo, W.; Chen, X.; Yang, L.; Hu, Y. Mater. Res. Bull. 2003, 38, 169-176. doi:10.1016/S0025-5408(02)00983-2

23. Javed, Q.; Feng-Ping, W.; Rafique, M. Y.; Toufiq, A. M.; Iqbal, M. Z. Chin. Phys. B 2012, 21, 117311-117317. doi:10.1088/1674-1056/21/11/117311

24. Yuan, Z.-Y.; Ren, T.-Z.; Du, G.; Su, B.-L. Chem. Phys. Lett. 2004, 389, 83-86. doi:10.1016/j.cplett.2004.03.064

25. Liu, L.; Yang, H.; Wei, J.; Yang, Y. Mater. Lett. 2011, 65, 694-697. doi:10.1016/j.matlet.2010.11.042

26. Dhaouadi, H.; Ghodbane, O.; Hosni, F.; Touati, F. ISRN Spectrosc. 2012, 2012, 1-8. doi:10.5402/2012/706398

27. Gillot, B.; El Guendouzi, M.; Laarj, M. Mater. Chem. Phys. 2001, 70, 54-60. doi:10.1016/S0254-0584(00)00473-9

28. Dimesso, L.; Heider, L.; Hahn, H. Solid State lonics 1999, 123, 39-46. doi:10.1016/S0167-2738(99)00107-1

29. Larcher, D.; Sudant, G.; Patrice, R.; Tarascon, J. Chem. Mater. 2003, 15, 3543-3551. doi:10.1021/cm030048m

30. Feitknecht, W. Pure Appl. Chem. 1964, 9, 423-440. doi:10.1351/pac196409030423

31. Oswald, H. R.; Wampetich, M. J. Helv. Chim. Acta 1967, 50, 2023-2034. doi:10.1002/hlca.19670500736

32. Punnoose, A.; Magnone, H.; Seehra, M. S. IEEE Trans. Magn. 2001, 37, 2150-2152. doi:10.1109/20.951107

33. Thota, S.; Prasad, B.; Kumar, J. Mater. Sci. Eng., B 2010, 167, 153-160. doi:10.1016/j.mseb.2010.01.049

34. Chakroune, N.; Viau, G.; Ammar, S.; Jouini, N.; Gredin, P.; Vaulay, M. J.; Fiévet, F. New J. Chem. 2005, 29, 355-361. doi:10.1039/b411117f

35. Sun, Y.; Hu, X.; Luo, W.; Huang, Y. J. Mater. Chem. 2012, 22, 19190-19195. doi:10.1039/c2jm32036c

36. Aminoff, G. Z. Kristallogr., Kristallgeom., Kristallphys., Kristallchem. 1926, 64, 475-490.

37. Ren, T.-Z.; Yuan, Z.-Y.; Hu, W.; Zou, X. Microporous Mesoporous Mater. 2008, 112, 467-473. doi:10.1016/j.micromeso.2007.10.025

38. Jiang, X.; Wang, Y.; Herricks, T.; Xia, Y. J. Mater. Chem. 2004, 14, 695-703. doi:10.1039/b313938g

39. Sawyer, D. T.; Chiericato, G., Jr.; Angells, C. T.; Nanni, E. J., Jr.; Tsuchiya, T. Anal. Chem. 1982, 54, 1720-1724. doi:10.1021/ac00248a014

40. Augustin, M.; Yezerska, O.; Fenske, D.; Bardenhagen, I.; Westphal, A.; Knipper, M.; Plaggenborg, T.; Kolny-Olesiak, J.; Parisi, J. Electrochim. Acta 2014, submitted. 


\section{License and Terms}

This is an Open Access article under the terms of the Creative Commons Attribution License

(http://creativecommons.org/licenses/by/2.0), which permits unrestricted use, distribution, and reproduction in any medium, provided the original work is properly cited.

The license is subject to the Beilstein Journal of Nanotechnology terms and conditions:

(http://www.beilstein-journals.org/bjnano)

The definitive version of this article is the electronic one which can be found at:

doi:10.3762/bjnano.6.6 